\title{
WATER EXTRACTS FROM THE COMBINATION OF COCCINIA GRANDIS (L.) VOIGT LEAVES AND AVERRHOA BILIMBI L. FRUITS WITH ANTIDIABETIC PROPERTIES: AN IN VITRO STUDY
}

\author{
MADE WISNU ADHI PUTRA I ${ }^{1 *}$, OLYN TIEN ATE ${ }^{2}$, GUSTI AYU WITA KUSUMAWATI I ${ }^{2}$, WAYAN NURSINI NI ${ }^{2}$
}

${ }^{1}$ Department of Biology, University of Dhyana Pura, Badung, Bali 80361, Indonesia. ${ }^{2}$ Department of Nutrition Science, University of Dhyana Pura, Badung, Bali 80361, Indonesia. Email: wisnuadhiputra@undhirabali.ac.id

Received: 30 December 2019, Revised and Accepted: 22 January 2020

\section{ABSTRACT}

Objective: The combination of two or more plants in a product can improve the nature of the activity of the compounds contained and reduce toxicity. This study was aimed to make water extracts from the combination of Coccinia grandis (L.) Voigt and Averrhoa bilimbi L. with antidiabetic properties.

Methods: The water extracts were made by decocting the combination of powdered Coccinia grandis (L.) Voigt leaves and Averrhoa bilimbi L. fruits at various mass ratios (1:0, 1:3, 1:1, 3:1, and 0:1) and various amounts of powdered samples (1-5 g). The process was done in 100 ml of boiling water for 5 min.

Results: The results showed that the highest total flavonoid content and total phenolic content of $135.1 \pm 0.18 \mathrm{mg}$ quercetin equivalent/g dry matter and $48.5 \pm 3.09 \mathrm{mg}$ gallic acid equivalent/g dry matter respectively, were found in the sample with a combination ratio of $1: 3$ ( $1 \mathrm{~g}$ ). The antioxidant activity test using the 2,2-diphenyl-1-picrylhydrazyl method showed that the sample with a combination ratio of 3:1 had the lowest value of $\mathrm{IC}_{50}(4.447 \pm 0.446 \mathrm{mg} / \mathrm{ml})$, which indicated the strongest radical scavenging activity, while the highest inhibition of $\alpha$-amylase activity in the sample with a combination ratio of $1: 1$ amounted to $1.086 \pm 0.264 \mathrm{mg} / \mathrm{ml}$.

Conclusion: In general, all combinations of Coccinia grandis (L.) Voigt leaves and Averrhoa bilimbi L. fruits had the potential as antidiabetic health beverages.

Keywords: Coccinia grandis (L.) Voigt, Averrhoa bilimbi L., Healthy beverages, Antidiabetic.

(C) 2020 The Authors. Published by Innovare Academic Sciences Pvt Ltd. This is an open access article under the CC BY license (http://creativecommons. org/licenses/by/4. 0/) DOI: http://dx.doi.org/10.22159/ajpcr.2020.v13i4.36732

\section{INTRODUCTION}

Type 2 diabetes mellitus (T2DM) is a disease caused by an increase in blood glucose levels due to insufficient insulin production in the pancreas or because the body cells experience insulin resistance. The risk of death of individuals with T2DM is twice as that of individuals who do not suffer from T2DM [1]. In 2014, there were 422 million people worldwide experiencing T2DM, and this amount is expected to increase in 2045 by 629 million people [2]. To date, the treatment of patients with T2DM has been very challenging. The administration of insulin and drugs such as sulfonylurea, metformin, and meglitinide apparently still has side effects such as hypoglycemia, fever, nausea, vomiting, diarrhea, and decreased appetite [3].

Treatment with medicines sourced from plant ingredients, often called herbal medicines, has become an alternative in reducing the side effects of using conventional medicines. Herbal medicines are proven to have antidiabetic activity and therapeutic properties in traditional treatment systems. In addition, herbs are easy to find, easy to process, and have no side effects [4]. Coccinia grandis (L.) Voigt is a plant that has long been used as an antidiabetic. The flavonoids and phenolics contained in the Coccinia grandis (L.) Voigt plant show the ability to inhibit the activity of $\alpha$-amylase and $\alpha$-glucosidase enzymes, regenerate $\beta$ cells in the pancreas, and have been shown to reduce blood glucose levels in diabetic rats [5-7]. Recently, there have been many studies on combinations of plants that have the same properties to be used as healthy beverages because they are more practical and more economical, for example, a combination of Limonium algarvense and Camellia sinensis L. [8] and a combination of $C$. sinensis black tea and Averrhoa bilimbi L. [9]. These combinations were proven to increase the activity of individual plants.

Averrhoa bilimbi L. is a plant that has traditionally been used to treat several diseases such as sore throat, eye pain, toothache, scabies, fever, hyperdipsia, and diabetes mellitus [10]. The phytochemical content in Averrhoa bilimbi L. includes flavonoids, steroids, triterpenoids, glycosides, proteins, fats, and vitamins A, B, and C [9]. In streptozotocininduced rats, Averrhoa bilimbi L. extract showed significant results in reducing blood glucose levels [11].

Based on the literature search, to date, the combination of Coccinia grandis (L.) Voigt leaves and Averrhoa bilimbi L. fruits as an antidiabetic health beverage has never been reported. This research was conducted to make water extracts from the combination of Coccinia grandis (L.) Voigt leaves and Averrhoa bilimbi L. fruits at various mass ratios and various sample masses. The resulted extracts were then tested for antidiabetic activities in vitro.

\section{MATERIALS AND METHODS}

\section{Materials}

Coccinia grandis (L.) Voigt leaves and Averrhoa bilimbi L. fruits were harvested from North Kuta, Bali, Indonesia, in February 2019. The leaves and fruits were identified in Pharmacognosy Laboratory, Pharmaceutical Biology Department, Faculty of Pharmacy, Universitas Gadjah Mada, Indonesia. Ethanol (96\%), methanol, aluminum chloride, potassium acetate, and phosphate buffer $\mathrm{pH} 7.4$ were purchased from Merck. Quercetin, 2,2-diphenyl-1-picrylhydrazyl (DPPH), $\alpha$-amylase, potassium iodate, starch, gallic acid, Folin-Ciocalteu reagent, sodium dihydrogen phosphate, and disodium hydrogen phosphate were purchased from Sigma Aldrich. Acarbose (Glucobay) was purchased from PT. Bayer Indonesia.

Preparation of combined healthy beverages

Coccinia grandis (L.) Voigt leaves and Averrhoa bilimbi L. fruits were washed and drained for $24 \mathrm{~h}$ at room temperature. The leaves and fruits were cut into small pieces and then dried using an oven at $50^{\circ} \mathrm{C}$ for 
Table 1: Total flavonoid content of healthy beverages at various mass ratios and amount of powdered plant samples

\begin{tabular}{|c|c|c|c|c|c|c|}
\hline \multirow[t]{2}{*}{ Samples } & \multirow[t]{2}{*}{ Ratio } & \multicolumn{5}{|c|}{ Total flavonoid content (mg QE/g d.m.) } \\
\hline & & $1 \mathrm{~g}$ & $2 \mathrm{~g}$ & $3 \mathrm{~g}$ & $4 \mathrm{~g}$ & $5 \mathrm{~g}$ \\
\hline $\mathrm{CG}$ & $1: 0$ & $134.91 \pm 2.63^{\mathrm{k}}$ & $115.56 \pm 2.60^{\mathrm{ijk}}$ & $117.33 \pm 2.23^{\mathrm{ijk}}$ & $108.40 \pm 7.72^{\mathrm{hij}}$ & $91.66 \pm 3.22^{\mathrm{efgh}}$ \\
\hline $\mathrm{CG}+\mathrm{AB}$ & $1: 1$ & $98.00 \pm 9.16^{\text {fghi }}$ & $74.09 \pm 2.74^{\text {bcde }}$ & $61.47 \pm 5.21^{\mathrm{fghi}}$ & $99.46 \pm 3.90^{\text {fghi }}$ & $82.68 \pm 2.05^{\text {cdefg }}$ \\
\hline $\mathrm{CG}+\mathrm{AB}$ & $1: 3$ & $135.14 \pm 0.18^{\mathrm{k}}$ & $75.18 \pm 3.22^{\text {bcde }}$ & $90.64 \pm 0.38^{\mathrm{efgh}}$ & $57.11 \pm 0.60^{\mathrm{ab}}$ & $50.50 \pm 0.48^{\mathrm{a}}$ \\
\hline $\mathrm{AB}$ & $0: 1$ & $123.42 \pm 5.13^{\mathrm{jk}}$ & $67.21 \pm 2.13^{\mathrm{abcd}}$ & $79.04 \pm 2.98^{\text {cdef }}$ & $103.32 \pm 2.27^{\mathrm{ghi}}$ & $86.19 \pm 0.12 \beta^{\mathrm{defg}}$ \\
\hline
\end{tabular}

Total flavonoid content values were represented in the mean \pm standard error of the mean ( $\mathrm{n}=3$ ). Different letters indicate significant difference based on Tukey test ( $\mathrm{p}<0.05)$. CG: Coccinia grandis L. Voigt, AB: Averrhoa bilimbi L. QE: Quercetin equivalent, d.m.: Dry matter

3 days. Samples of dried leaves and fruits were crushed with a blender (Philips) then sifted to powder. The preparation of water extracts was carried out at a variety of mass ratios $(1: 0,3: 1,1: 1,1: 3$, and $0: 1)$ and various sample masses (1-5 g). The powder sample was decocted with $100 \mathrm{ml}$ of hot water at $100^{\circ} \mathrm{C}$ for 5 min then filtered and allowed to stand until room temperature.

\section{The determination of total flavonoid content (TFC)}

The TFC of water extracts was determined using the aluminum chloride colorimetric method [12]. A total of $0.50 \mathrm{ml}$ of sample was mixed with $1.5 \mathrm{ml}$ of $95 \%$ ethanol, followed by the addition of $0.10 \mathrm{ml}$ of $10 \%$ aluminum chloride, $0.10 \mathrm{ml}$ of $1 \mathrm{M}$ potassium acetate, and $2.8 \mathrm{ml}$ of distilled water. The resulting mixture was incubated at $27^{\circ} \mathrm{C}$ for $30 \mathrm{~min}$. The absorbance was measured using a ultraviolet (UV)-visible spectrometer (Thermo Scientific Genesys $10 \mathrm{~S}$ UV-Vis) at $415 \mathrm{~nm}$. The flavonoid content was calculated using standard calibration of quercetin solution in the range of $0-25 \mu \mathrm{g}\left(\mathrm{y}=0.0092 \mathrm{x}+0.003, \mathrm{R}^{2}=0.9979\right)$. The results are expressed as quercetin equivalent micrograms $(\mathrm{QE}) / \mathrm{g}$ dry matter.

\section{The determination of total phenolic content (TPC)}

The TPC test was carried out using the method of Bi et al. [13] using Folin-Ciocalteu as a reagent and gallic acid as a standard. A total of $10 \mu \mathrm{l}$ of the sample was diluted with $90 \mu \mathrm{l}$ of distilled water, added with $200 \mu \mathrm{l}$ of Folin-Ciocalteu solution and $800 \mu \mathrm{l}$ of $700 \mathrm{nM} \mathrm{Na}_{2} \mathrm{CO}_{3}$. The mixture was then incubated for $30 \mathrm{~min}$ at room temperature before spectrophotometric analysis. After incubation $(30 \mathrm{~min}$, room temperature), the absorbance of the solution was measured at a wavelength of $765 \mathrm{~nm}$. Determination of total phenolic was based on the linear regression equation obtained from the standard calibration curve of gallic acid at the concentration of $0-100 \mathrm{ppm}(\mathrm{y}=0.0087 \mathrm{x}+0.0509$, $\mathrm{R}^{2}=0.9453$ ). The result of the total phenolic calculation is expressed as gallic acid equivalent (GAE)/g dry matter.

\section{The determination of DPPH antioxidant activity}

Antioxidant activity test was performed based on Attanayake et al. [12] using the DPPH solution. The sample $(20 \mu \mathrm{l})$ was diluted with $480 \mu \mathrm{l}$ of distilled water and added with $2.0 \mathrm{ml}$ of DPPH solution in $0.004 \%$ ethanol. The mixture was shaken strongly, then allowed to stand at room temperature for $30 \mathrm{~min}$. Ethanol was used as a blank sample. The absorbance of the sample was measured at a wavelength of $517 \mathrm{~nm}$ using a UV-visible spectrometer. The percentage of inhibition (\%inhibition) can be calculated using the formula below:

$$
\% \text { Inhibition }=\frac{A_{c}-A_{s}}{A_{c}} \times 100
$$

Where $A_{c}$ represents the absorbance of the control and $A_{s}$ represents the absorbance of the sample. The antioxidant activity is expressed as the $\mathrm{IC}_{50}$ value $(\mathrm{mg} / \mathrm{ml})$ obtained from the plot of \% inhibition against sample concentration. All tests were carried out in triplicate. The results were expressed as the mean \pm standard error of the mean (SEM) of the inhibition concentration $\left(\mathrm{IC}_{50}\right)$.

\section{The determination of $\alpha$-amylase inhibitory activity}

The determination of $\alpha$-amylase inhibitory activity was carried out in vitro by the iodine-starch test using the method of Neagu et al. [14].
A total of $30 \mu \mathrm{l}$ of the sample was mixed with $50 \mu \mathrm{l}(400 \mu \mathrm{l} / \mathrm{ml})$ of starch in phosphate buffer ( $0.25 \mathrm{M}$; pH 7.0). After 30 min being incubated at $37^{\circ} \mathrm{C}, 10 \mu \mathrm{l} \alpha$-amylase (50 $\mu \mathrm{g} / \mathrm{ml}$ in phosphate buffer) was added to the mixture, then followed by adding $10 \mu \mathrm{l}$ of $0.25 \mathrm{M}$ phosphate buffer. Afterward, $50 \mu \mathrm{l}$ of $0.01 \mathrm{~N}$ iodine solution and $1300 \mu \mathrm{l}$ of distilled water were added to the mixture. Absorbance measurement using a UV-visible spectrometer was performed at a wavelength of $660 \mathrm{~nm}$. All tests were carried out in triplicate. Similar to the DPPH antioxidant activity, the $\alpha$-amylase inhibitory activity was also expressed as the mean \pm SEM of the inhibition concentration $\left(\mathrm{IC}_{50}\right)$.

\section{Data analysis}

All research data are expressed as the mean \pm SEM, and all experiments were carried out in triplicate. Significant differences were assessed by the normality test, followed by the analysis of variance (ANOVA) test. If there were significant differences when the value of $p<0.05$, the test was followed by the Tukey test. The statistical analysis was performed using SPSS v.24 statistical analysis (IBM).

\section{RESULTS AND DISCUSSION}

\section{TFC}

Flavonoids are secondary metabolites of plants that function as antioxidants to ward off free radicals [15]. The addition of $\mathrm{AlCl}_{3}$ solution in the experiment was intended to form a complex compound that causes a shift in the wavelength toward the visible. It was marked by a change in the color of the sample from light yellow to a brighter yellow [16]. The intensity of the color formed was then measured using a UV-visible spectrometer at a wavelength of $415 \mathrm{~nm}$.

Table 1 shows the results of TFC of water extracts at various combination ratios and total sample masses. Among all combinations, the sample that had the highest total flavonoid was $\mathrm{CG}+\mathrm{AB}$ with a ratio of $1: 3(135.14 \pm 0.18 \mathrm{mg} Q E / g$ d.m.). In general, the addition of $A B$ in the combination samples could increase the TFC. Flavonoid is thermally stable with time and temperature so that during high temperature in the decoction process, it did not cause unfavorable degradation and contributed well to CG [17]. The results of the analysis using ANOVA $(p<0.05)$ showed significantly different values for each sample. The results of further tests using the Tukey test showed that each sample had a significant difference in total flavonoids.

The TFC values in this study varied. The higher the total mass of powdered samples, the lower the total flavonoid they had. When extracting $1 \mathrm{~g}$ of sample powder using $100 \mathrm{ml}$ of water, it was found that the flavonoid compound which escaped from the sample was completely absorbed by water. This happens because of the balance between the substances that come out and the amount of water added. When the mass of the powdered sample increased and the water used to extract it remained, reabsorption of flavonoid substances occurred. The pharmacokinetic activity of flavonoids is closely related to its functional groups so that it arises from other chemical components present in the extract, resulting in total flavonoid instability at each concentration [16]. The choice of solvent greatly influenced the flavonoid content in the samples. Solvents such as methanol and ethanol have been more widely used for the extraction of phenolics and flavonoids from plants compared to 
Table 2: Total phenolic content of healthy beverages at various mass ratios and amount of powdered plant samples

\begin{tabular}{|c|c|c|c|c|c|c|}
\hline \multirow[t]{2}{*}{ Samples } & \multirow[t]{2}{*}{ Ratio } & \multicolumn{5}{|c|}{ Total phenolic content (mg GAE/g d.m.) } \\
\hline & & $1 \mathrm{~g}$ & $2 \mathrm{~g}$ & $3 \mathrm{~g}$ & $4 \mathrm{~g}$ & $5 \mathrm{~g}$ \\
\hline CG & 1:0 & $41.52 \pm 3.68^{\mathrm{k}}$ & $24.89 \pm 1.70^{\text {ghi }}$ & $17.36 \pm 0.14^{\mathrm{abcde}}$ & $13.45 \pm 0.31^{\mathrm{ab}}$ & $13.13 \pm 1.14^{\mathrm{a}}$ \\
\hline $\mathrm{CG}+\mathrm{AB}$ & $3: 1$ & $27.49 \pm 0.15^{\text {hij }}$ & $15.78 \pm 0.49^{\text {abcd }}$ & $16.84 \pm 0.23^{\text {abcde }}$ & $14.29 \pm 0.95^{\mathrm{abc}}$ & $15.66 \pm 1.65^{\mathrm{abcd}}$ \\
\hline $\mathrm{CG}+\mathrm{AB}$ & $1: 1$ & $28.12 \pm 0.97^{\mathrm{ij}}$ & $33.28 \pm 0.20^{j}$ & $24.68 \pm 0.46^{\text {fghi }}$ & $22.04 \pm 1.06^{\text {efghi }}$ & $22.04 \pm 0.16^{\text {defghi }}$ \\
\hline $\mathrm{CG}+\mathrm{AB}$ & $1: 3$ & $48.48 \pm 3.09^{\mathrm{k}}$ & $21.37 \pm 2.35^{\text {cdefghi }}$ & $17.60 \pm 0.23^{\mathrm{abcdef}}$ & $15.11 \pm 0.04 \mathrm{abc}$ & $15.08 \pm 0.03^{\mathrm{abcd}}$ \\
\hline $\mathrm{AB}$ & $0: 1$ & $24.75 \pm 1.86^{\text {fghi }}$ & $27.08 \pm 0.14^{\text {hij }}$ & $17.74 \pm 0.88^{\text {abcdefg }}$ & $23.19 \pm 0.25^{\text {efghi }}$ & $20.42 \pm 0.89^{\text {bcdefgh }}$ \\
\hline
\end{tabular}

Total phenolic content values were represented in the mean \pm standard error of the mean $(n=3)$. Different letters indicate a significant difference based on Tukey test $(\mathrm{p}<0.05)$. CG: Coccinia grandis L. Voigt, AB: Averrhoa bilimbi L., GAE: Gallic acid equivalent, d.m.: Dry matter

Table 3: Antioxidant and inhibition of $\alpha$-amylase activity values of healthy beverages at various mass ratios

\begin{tabular}{|c|c|c|c|}
\hline Samples & Ratio & $\begin{array}{l}\text { Antioxidant activity, } \\
\mathrm{IC}_{50}(\mathrm{mg} / \mathrm{ml})\end{array}$ & $\begin{array}{l}\text { Inhibition of } \alpha \text {-amylase, } \\
\mathrm{IC}_{50}(\mathrm{mg} / \mathrm{ml})\end{array}$ \\
\hline CG & $1: 0$ & $8.04 \pm 0.03^{b}$ & $0.40 \pm 0.03^{\mathrm{a}}$ \\
\hline $\mathrm{CG}+\mathrm{AB}$ & $3: 1$ & $4.45 \pm 0.45^{\mathrm{a}}$ & $2.73 \pm 0.30^{\mathrm{b}}$ \\
\hline $\mathrm{CG}+\mathrm{AB}$ & $1: 1$ & $6.18 \pm 0.66^{\mathrm{ab}}$ & $1.09 \pm 0.26^{\mathrm{a}}$ \\
\hline $\mathrm{CG}+\mathrm{AB}$ & $1: 3$ & $7.60 \pm 0.79^{b}$ & $1.50 \pm 0.37^{\mathrm{a}}$ \\
\hline $\mathrm{AB}$ & $0: 1$ & $4.00 \pm 0.08^{\mathrm{a}}$ & $0.52 \pm 0.25^{\mathrm{a}}$ \\
\hline Acarbose* & - & - & $3.86 \pm 0.07^{b}$ \\
\hline \multicolumn{4}{|c|}{$\begin{array}{l}\mathrm{IC}_{50} \text { values were represented in the mean } \pm \text { standard error of the mean } \\
(\mathrm{n}=3) \text {. Different letters indicate a significant difference based on Tukey test } \\
(\mathrm{p}<0.05) \text {. CG: Coccinia grandis L. Voigt, AB: Averrhoa bilimbi L., IC } \mathrm{C}_{50}: \text { Inhibitory } \\
\text { concentration }\end{array}$} \\
\hline
\end{tabular}

water [18]. In line with the research conducted by Do et al. [19], the total flavonoids, phenolic, and antioxidant activity of the extract of Limnophila aromatica were higher when pure acetone and pure ethanol were used than when methanol and water were. However, the use of water is very effective because it can be consumed directly by people. Overall, the results obtained in this study indicate that the combination of the $\mathrm{CG}$ and $\mathrm{AB}$ contains total flavonoids that can be used as a healthy beverage to prevent oxidative stress and complications of diabetes. The previous studies have reported that the combination of Terminalia catappa L. and Colocasia esculenta L. at a ratio of 1:1 had a TFC of $27.69 \pm 0.30 \mathrm{mg} \mathrm{QE} / \mathrm{g}$, demonstrating potential as a natural antioxidant and good antimicrobial [20].

TPC

Phenolic is a group of bioactive compounds that are found in plants and have free radical scavenging activity [21]. The determination of TPC in the sample was done using a Folin-Ciocalteu solution and added with sodium carbonate so that it changes color from yellow to blue. The blue discoloration is caused by the formation of phenolic ions in the sample solution. Phenolate ions are only present in base solutions, whereas Folin-Ciocalteu reagents and products produced are unstable under alkaline conditions [22]. The blue color formed is more concentrated, which is equivalent to the concentration of phenolic ions formed. This means that the greater the concentration of phenolic compounds, the more phenolic ions that reduce hetropoly acid so that the resulting blue color becomes more concentrated [23].

The results of the TPC test are shown in Table 2. The TPC of CG+AB $(1 \mathrm{~g})$ with a ratio of 1:3 was higher than that of individual extracts (CG and $\mathrm{AB}$ ). The increase was caused by an increase in $\mathrm{AB}$ mass, which contributed to the addition of phenolic amounts in $C G+A B$. In addition, the stability of phenolic compounds in $C G+A B(1: 3)$ also caused an increase in total phenolic levels. Phenolic compounds are less degraded at high temperatures or long extraction times [17]. Increased extraction temperatures can increase the solubility of phenolic compounds and increase the rate of mass transfer [18]. Maizura et al. reported that the combination of Polygonum minus and Zingiber officinale had a TPC of $132.0 \mathrm{mg} \mathrm{GAE} / \mathrm{g}$ extract, which shows the potential as significant free radical scavengers [21]. Similar to total flavonoids, total phenolic levels in this study also declined with increasing mass of plant powder samples. The mechanism of phenolic readsorption back to the plant matrix is one thing responsible for this phenomenon. Statistical analysis using ANOVA $(\mathrm{p}<0.05)$ showed significantly different values for each sample. The results of further tests using the Tukey test showed that each sample had a total phenolic difference.

\section{DPPH antioxidant activity}

The antioxidant can delay or inhibit cell damage from free radicals that exist in biological systems or that are produced in various metabolic processes. In addition, antioxidants play a central role in health care to prevent various chronic diseases as well as premature aging [24]. The results of the antioxidant activity assay showed that all extracts have the ability to inhibit DPPH free radicals (Table 3). The ability of the extracts to scavenge DPPH free radicals was characterized by fading the purplecolored solution [25]. This color fading decreased the absorbance value of visible light on UV-visible spectrometers. The lower the absorbance value means, the higher the antioxidant activity possessed.

Table 3 shows that the $\mathrm{CG}+\mathrm{AB}$ with a ratio of $3: 1,1: 1$, and $1: 3 \mathrm{had}$ antioxidantactivity $\left(\mathrm{IC}_{50}\right)$ of $4.45 \pm 0.45,6.18 \pm 0.66$, and $7.60 \pm 0.79 \mathrm{mg} / \mathrm{ml}$, respectively. These $\mathrm{IC}_{50}$ values are smaller (stronger antioxidant activity) compared to individual CG samples, which are $8.04 \pm 0.03 \mathrm{mg} / \mathrm{ml}$. This indicates that the addition of AB to CG can increase antioxidant activity, with the best combination being at a ratio of $3: 1$. Statistical analysis using ANOVA $(\mathrm{p}<0.05)$ showed significantly different values for each sample. The results of further tests using the Tukey test showed that some samples had differences in antioxidant activity.

The antioxidant potential of plant extracts is influenced by phenolic and flavonoid compounds. Indeed, phenolic can directly reduce oxidative stress [26]. It has been reported that phenolic and flavonoid compounds have a high scavenging ability associated with the hydroxyl groups present in these compounds [27]. Antioxidant activity is used to prevent chronic diseases by protecting organisms from the production of reactive oxygen species. Thus, it is important to replace synthetic antioxidants with natural antioxidants because of its lower toxicity and side effects [28]. Nedamani et al. showed that the combination of green tea (C. sinensis), rosemary (Rosmarinus officinalis), and oak fruit (Quercus branti) extracts had better activity than butylated hydroxytoluene. It was also reported that there was a direct relationship between total phenolic and antioxidant activity of combined extracts [29].

\section{$\alpha$-Amylase inhibitory activity}

Inhibiting the activity of enzymes that hydrolyze carbohydrates such as $\alpha$-amylase is an efficient way to reduce postprandial blood glucose levels [30]. Inhibition of these enzymes is very important in overcoming hyperglycemia associated with T2DM [31]. Inhibition of $\alpha$-amylase contributes to improving the symptoms of T2DM and delays glucose absorption due to the slow digestion of starch [32]. Drugs such as acarbose, miglitol, and voglibose have the ability to inhibit the activity of the $\alpha$-amylase enzyme. However, the side effects produced by these synthetic drugs are very disturbing [33].

The results of this study indicate that all extracts have the ability to inhibit the performance of the $\alpha$-amylase enzyme, as shown in Table 3. The inhibition of $\alpha$-amylase activity of CG extract 
was greater $\left(\mathrm{IC}_{50}=0.40 \pm 0.03 \mathrm{mg} / \mathrm{ml}\right)$ than that of $\mathrm{AB}$ extract $\left(\mathrm{IC}_{50}=0.524 \pm 0.253 \mathrm{mg} / \mathrm{ml}\right)$. Meanwhile, $\mathrm{CG}+\mathrm{AB}$ extracts with ratios of $3: 1,1: 1$, and $1: 3$ had $I_{50}$ values of $2.73 \pm 0.30,1.09 \pm 0.26$, and $1.50 \pm 0.37 \mathrm{mg} / \mathrm{ml}$, respectively. Among all these combinations, the sample that had the highest $\alpha$-amylase enzyme inhibitory activity was $\mathrm{CG}+\mathrm{AB}(1: 1)$ with an $\mathrm{IC}_{50}$ value of $1.09 \pm 0.26 \mathrm{mg} / \mathrm{ml}$. The flavonoid and phenolic contents found in $C G$ and $A B$ have the potential to inhibit the activity of the $\alpha$-amylase enzyme in diabetic rats [34,35]. Flavonoid and phenolic compounds present in the $\mathrm{CG}$ and $\mathrm{AB}$ also act as antioxidants in protecting pancreatic cells from oxidation damage and are able to regenerate damaged beta cells of the pancreas so that they can function properly [5,11]. In addition to flavonoids, these compounds play a role in improving glucose tolerance, stimulating glucose uptake in peripheral tissues, and regulating the activity of enzymes involved in carbohydrate metabolism [36]. The results of the analysis using ANOVA $(p<0.05)$ showed significantly different values for each sample, which then were confirmed by the Tukey test.

This study used acarbose as a positive control with an $\mathrm{IC}_{50}$ value of $3.86 \pm 0.07 \mathrm{mg} / \mathrm{ml}$. This shows that the combination samples had better $\alpha$-amylase inhibitory activity compared to positive control and could be used as innovative healthy beverages for the treatment of T2DM. Contrary to research by Rodrigues et al., health drinks combined with sea lavender and green tea did not show an $\alpha$-amylase inhibitory activity but had a better $\alpha$-glucosidase enzyme inhibiting activity compared to acarbose [8].

\section{CONCLUSION}

In this study, the combination of Coccinia grandis (L.) Voigt leaves and Averrhoa bilimbi L. fruit showed good properties as healthy beverages. The combination samples showed higher total flavonoid and total phenolic values compared to individual samples. Antioxidant activity and $\alpha$-amylase inhibition tests showed that the combination samples have excellent potential as antidiabetic healthy beverages. This research can be used as a basis for further research in the framework of the exploration of plants that have efficacy as antidiabetic. Further testing on animals is highly recommended to understand the mechanism of the action of these water extracts.

\section{ACKNOWLEDGMENT}

The authors would like to thank the Science and Health Laboratory, University of Dhyana Pura, for providing the facilities to carry out the research.

\section{AUTHORS' CONTRIBUTIONS}

I Made Wisnu Adhi Putra concepted the research, provided the methods, and authored the manuscript. Olyn Tien Ate conducted experiment in the laboratory and analyzed the obtained data. I Gusti Ayu Wita Kusumawati and Ni Wayan Nursini analyzed the obtained data and authored the manuscript.

\section{CONFLICTS OF INTEREST}

All authors have none to declare.

FUNDING

This research received financial assistance from The Research and Community Service Institution, University of Dhyana Pura, through the Hibah Unggulan Perguruan Tinggi (Higher Education Excellent Grants) 2019 with contract number: 036/UNDHIRA-LP2M/PN/2019.

\section{REFERENCES}

1. Upadhyay J, Polyzos SA, Perakakis N, Thakkar B, Paschou SA, Katsiki N, et al. Pharmacotherapy of Type 2 diabetes: An update. Metabolism 2018;78:13-42.

2. Assaad Khalil SH, Megallaa MH, Rohoma KH, Ismael H, AbouSeif M, Kharboush I, et al. Prevalence of Type 2 diabetes mellitus in a sample of the adult population of Alexandria, Egypt. Diabetes Res Clin Pract 2018;144:63-73.

3. Gómez-Huelgas R, Gómez Peralta F, Rodríguez Mañas L, Formiga F, Puig Domingo M, Mediavilla Bravo JJ, et al. Treatment of Type 2 diabetes mellitus in elderly patients. Rev Clin Esp 2018;218:74-88.

4. Arumugam G, Manjula P, Paari N. A review: Anti diabetic medicinal plants used for diabetes mellitus. J Acute Dis 2013;2:196-200.

5. Attanayake AP, Jayatilaka KA, Pathirana C, Mudduwa LK. Antihyperglycemic activity of Coccinia grandis (L.) Voigt in streptozotocin induced diabetic rats. Indian J Tradit Knowl 2015;14:376-81.

6. Waisundara VY, Watawana MI, Jayawardena N. Costus speciosus and Coccinia grandis: Traditional medicinal remedies for diabetes. S Afr J Bot 2015;98:1-5

7. Mohammed SI, Chopda MZ, Patil RH, Vishwakarma KS, Maheshwari VL. In vivo antidiabetic and antioxidant activities of Coccinia grandis leaf extract against streptozotocin induced diabetes in experimental rats. Asian Pac J Trop Dis 2016;6:298-304.

8. Rodrigues MJ, Oliveira M, Neves V, Ovelheiro A, Pereira CA, Neng NR, et al. Coupling sea lavender (Limonium algarvense Erben) and green tea (Camellia sinensis (L.) Kuntze) to produce an innovative herbal beverage with enhanced enzymatic inhibitory properties. S Afr J Bot 2019;120:87-94.

9. Anggraini T, Febrianti F, Aisman, Ismanto SD. Black tea with Averrhoa bilimbi L extract: A healthy beverage. Agric Agric Sci Procedia 2016;9:241-52.

10. Khanam Z, Sam KH, Zakaria NH, Ching CH, Bhat IU. Determination of polyphenolic content, HPLC analyses and DNA cleavage activity of Malaysian Averrhoa carambola L. fruit extracts. J King Saud Univ Sci 2015;27:331-7.

11. Kurup SB, Mini S. Averrhoa bilimbi fruits attenuate hyperglycemiamediated oxidative stress in streptozotocin-induced diabetic rats. J Food Drug Anal 2017;25:360-8.

12. Attanayake AP, Jayatilaka KA, Mudduwa LK, Pathirana C. In vivo antihyperlipidemic, antioxidative effects of Coccinia grandis (L.) Voigt (Cucurbitaceae) leaf extract: An approach to scrutinize the therapeutic benefits of traditional Sri Lankan medicines against diabetic complications. Int J Pharm Sci Res 2016;7:3949-58.

13. Bi W, Shen J, Gao Y, He C, Peng Y, Xiao P. Ku-jin tea (Acer tataricum subsp. ginnala or A. tataricum subsp. theiferum), an underestimated functional beverage rich in antioxidant phenolics. J Funct Foods 2016;24:75-84.

14. Neagu E, Radu GL, Albu C, Paun G. Antioxidant activity, acetylcholinesterase and tyrosinase inhibitory potential of Pulmonaria officinalis and Centarium umbellatum extracts. Saudi J Biol Sci 2018;25:578-85.

15. Aryal S, Baniya MK, Danekhu K, Kunwar P, Gurung R, Koirala N. Total phenolic content, flavonoid content and antioxidant potential of wild vegetables from Western Nepal. Plants (Basel) 2019;8:1-12.

16. Subedi L, Timalsena S, Duwadi P, Thapa R, Paudel A, Parajuli K. Antioxidant activity and phenol and flavonoid contents of eight medicinal plants from Western Nepal. J Tradit Chin Med 2014;34:584-90.

17. Muhamad N, Muhmed SA, Yusoff MM, Gimbun J. Influence of solvent polarity and conditions on extraction of antioxidant, flavonoids and phenolic content from Averrhoa bilimbi. J Food Sci Eng 2014;4:255-60.

18. Dai J, Mumper RJ. Plant phenolics: Extraction, analysis and their antioxidant and anticancer properties. Molecules 2010;15:7313-52.

19. Do QD Angkawijaya AE, Tran-Nguyen PL, Huynh LH, Soetaredjo FE, Ismadji $\mathrm{S}$, et al. Effect of extraction solvent on total phenol content, total flavonoid content, and antioxidant activity of Limnophila aromatica. J Food Drug Anal 2014;22:296-302.

20. Chanda S, Rakholiya K, Dholakia K, Baravalia Y. Antimicrobial, antioxidant, and synergistic properties of two nutraceutical plants: Terminalia catappa L. and Colocasia esculenta L. Turk J Biol 2013;37:81-91

21. Maizura M, Aminah A, Wan Aida WM. Total phenolic content and antioxidant activity of kesum (Polygonum minus), ginger (Zingiber officinale) and turmeric (Curcuma longa) extract. 2011;534:529-34.

22. Rompas DE, Runtuwene MR, Koleangan HS. Analisis kandungan fitokimia dan uji aktivitas antioksidan dari tanaman lire (Hemigraphis repanda (L) Hall F.). J MIPA Unsrat Online 2015;5:36-9.

23. Kusbandari A, Prasetyo DY, Susanti H. Penetapan kadar fenolik total dan aktivitas antioksidan ekstrak etanol daun kopi kawa dengan metode DPPH. Media Farm 2018;15:72-80.

24. Tuyen PT, Khang DT, Minh LT, Minh TN, Thu Ha PT, Elzaawely AA, et al. Phenolic compounds and antioxidant activity of Castanopsis phuthoensis and Castanopsis grandicicatricata. Int Lett Nat Sci 
2016;55:77-87.

25. Loganathan $\mathrm{K}$, Bai VN. High frequency in vitro plantlet regeneration and antioxidant activity of Enicostema axillare (Lam.) Raynal ssp. littoralis (Blume) Raynal: An important medicinal plant. Asian Pac J Reprod 2014;3:241-8.

26. Jain DP, Pancholi SS, Patel R. Synergistic antioxidant activity of green tea with some herbs. J Adv Pharm Technol Res 2011;2:177-83.

27. Rahman MM, Habib MR, Hasan MA, Al Amin M, Saha A, Mannan A. Comparative assessment on in vitro antioxidant activities of ethanol extracts of Averrhoa bilimbi, Gymnema sylvestre and Capsicum frutescens. Pharmacogn Res 2014;6:36-41.

28. Rodrigues MJ, Soszynski A, Martins A, Rauter AP, Neng NR, Nogueira JM, et al. Unravelling the antioxidant potential and the phenolic composition of different anatomical organs of the marine halophyte Limonium algarvense. Ind Crops Prod 2015;77:315-22.

29. Ranjbar NedamaniE, Sadeghi MahoonakA, Ghorbani M, KashaninejadM. Evaluation of antioxidant interactions in combined extracts of green tea (Camellia sinensis), rosemary (Rosmarinus officinalis) and oak fruit (Quercus branti). J Food Sci Technol 2015;52:4565-71.

30. Kazeem MI, Adamson JO, Ogunwande IA. Modes of inhibition of $\alpha$-amylase and $\alpha$-glucosidase by aqueous extract of Morinda lucida Benth leaf. Biomed Res Int 2013;2013:527570.
31. Baessa M, Rodrigues MJ, Pereira C, Santos T, da Rosa Neng N, Nogueira JM, et al. A comparative study of the in vitro enzyme inhibitory and antioxidant activities of Butea monosperma (Lam.) Taub. and Sesbania grandiflora (L.) Poiret from Pakistan: New sources of natural products for public health problems. S Afr J Bot 2019;120:146-56.

32. Jemaa HB, Jemia AB, Khlifi S, Ahmed HB, Slama FB, Benzarti A, et al. Antioxidant activity and a-amylase inhibitory potential of Rosa canina L. Afr J Tradit Complement Altern Med 2017;14:1-8.

33. Punnagai K, Josephine GI. Alpha-amylase and alpha-glucosidase inhibitory effects of Calliandra haematocephala and its potential role in diabetes mellitus. Asian J Pharm Clin Res 2018;11:429-32.

34. Chowdhury SS, Uddin GM, Mumtahana N, Hossain M, Hasan SM. In-vitro antioxidant and cytotoxic of hydromethanolic extract of Averrhoa bilimbi L. fruits. Int J Pharm Sci Res 2012;3:2263-8.

35. Meenatchi P, Purushothaman A, Maneemegalai S. Antioxidant, antiglycation and insulinotrophic properties of Coccinia grandis in vitro: Possible role in prevention of diabetic complications. J Tradit Complement Med 2017;7:54-64.

36. Sahgal G, Ramanathan S, Sasidharan S, Mordi MN, Ismail S, Mansor SM. Brine shrimp lethality and acute oral toxicity studies on Swietenia mahagoni (Linn.) Jacq. seed methanolic extract. Pharmacogn Res 2010;2:215-20. 